\title{
Feminist Metodoloji Tartışmaları
}

\author{
Feminist Methodological Discussions
}

\section{Sevinç GÜÇL $\ddot{U}^{*}$}

Özet: Bu makalede modernleşme sürecinde ortaya çıkan bilim ve metod anlayışı ile bu anlayışa yöneltilen eleştiri ve özelde de feminist eleştiri bağlamında feminist metodoloji tartışmaları ele alınmıştır. Makale dört bölümden oluşmaktadır. İlk bölümde modernleşme ve bilim, ikinci bölümde modernleşme ve bilim anlayışına yöneltilen feminist eleştiriler, üçüncü bölümde feminist bir metodolojinin olanakları konusundaki görüş ve tartışmalar, dördüncüde de çağdaş, postmodern ve postkolonyal tartı̧malar yer almaktadır. Metod konusundaki bir makalede kuramsal bakış açılarına da kaçınılmaz olarak değinilmiştir.

Anahtar Sözcükler: Bilimsel metod, pozitivizm, feminist eleştiri, modernizm, postmodernizm

Abstract: Within the context of feminist criticism this article examines the thinking concerning science and methods in the process of modernization and discussions of feminist methodology. This study consists of four parts. The first part examines the relationship of modernization and science; feminist criticism forms the subject of the second part. Feminist opinions and discussions concerning the possibilities of feminist methodology form the third part and modern, postmodern and postcolonial discourse are the subject of the final part. Theoretical perspectives are discussed in this article.

Keywords: Scientific method, positivism, feminist criticism, modernism, postmodernism

Bilim ve bilimsel yöntemi kadın araştırmaları açısından ele aldığımızda karşımıza iki yol çıkmaktadır: Mevcut sosyal bilim metodlarını kadın konusuna uyarlamak veya mevcut sosyal bilim metodlarına getirilen feminist eleştiri bağlamında kadın konusundaki araştırmaları gerçekleştirmek. Acaba kadın çalışmaları konusunda feminist bakış açısı nasıl oluşturulabilir? Sınırları çizilmiş bir kadın çalışmaları alanı ve metodolojisi oluşturulabilir mi? Kadın çalışmaları disiplinler arası bir alan mıdır? Kadın çalışmaları alanında kadın ve diğerleri (ekonomi, hukuk, eğitim, sağlık vb.) şeklinde araştırmalar yaparak kadın konusunu açıklamış olur muyuz? Gerek batıda gerek ülkemizde bu ve buna benzer sorular sıkça sorulmakta ve tartışılmaktadır. Bu soruya getirilebilecek yanıtlar, hem bilimsel metodolojinin gelişimi konusundaki dönemler hem de buna koşut olarak feminist düşüncenin gelişimindeki dönemler ele alınarak verilebilir. Makalemizde metodoloji sözcüğü, belirli bir disiplin içinde çalışmanın nasıl ilerlediği, araştırmanın nasıl yürütüldüğü, bilimin amacı ve akıl yürütme biçimlerinin neler olduğu üzerinde odaklaşacak şekilde kullanılmıştır. Yine dayanılan kaynaklarda yöntem veya metod kavramı genel olarak verileri toplama teknikleri şeklinde ele alınmıştır.

Benzer soruların dile getirildiği, 23-24 Ocak 2003 tarihleri arasında Ankara Üniversitesi Kadın Çalışmaları Ana Bilim Dalı ev sahipliğinde yapılan "Üniversitede Kadın Çalışmaları" toplantısında kadın çalışmalarında kavramsal ve metodolojik sorunlar başlığı altında disiplinlerarasılık, feminist bilgi üretimi ve feminist metodoloji ve teknikler konuları tartışılmıştır.

\footnotetext{
* Prof. Dr., Akdeniz Üniversitesi, Edebiyat Fakültesi, Sosyoloji Bölümü, Antalya, sguclu@akdeniz.edu.tr
} 
Disiplinlerarasılığın yeterince uygulanmadığı dile getirilmiştir. Feminist bilgi üretimi başlığı altında belirginleşen temel soru, kadınları bilginin nesnesi olarak tanımlamanın feminist bilgi üretimi anlamında yeterli olup olmadığı ve bunun doğru strateji olup olmadığıdır. Toplantı katılımcılarının anlaşmaya varmış göründükleri temel görüş, Sirman'ın "cinslendirilme" kavramıyla anlattığı gibi, cinsiyet ayrımı etrafında şekillenen ve bu ayrımın sirayet ettiği mevcut tüm iktidar ilişkilerinin oluşturduğu yapıların feminist bilginin nesneleri olabileceği yönündedir. Böyle kavranan ve uygulanan bir "kadın çalışmaları" hiç kuşkusuz, yalnızca kadınlara yönelik ve kadınlara hizmet eden bir alan olmaktan çıkacak ve genelde bilgi üretimine, dolayısıyla genel bir kategori olarak cinslendirilmiş bilime katkıda bulunacaktır. Toplantıda feminist metodoloji, "bilim"i tüm geleneksel bilme biçimlerini dönüştüren eleştirel bir potansiyel olarak ele alındı. Araştırmacı ve araştırma nesneleri arasındaki hiyerarşiyi ortadan kaldıran, araştırmacıyı, araştırma nesnesi ile özdeşlik ilişkisine sokan, aşağıdan bakmayı becerebilen, araştırmayı politik mücadelenin ayrılmaz parçası kılan ve araştırma ile uygulamayı bütünleştiren feminist metodoloji(ler), bilimin canlı toplumsal süreçlerde, yaşantı ve deneyimlerde köklendiğini ortaya koymaktadır. Feminist metodolojinin uyguladığı teknikler de bu kökleri ortaya çıkarma araçları olarak görülmelidir (Timisi, 2002-2003, 202-207).

Hangi çalışmaların kadın çalışması olarak düşünülebileceği konusunda Yıldız Ecevit'in bibliyografik araştırması bize 1şık tutabilir. Kadın konusunda 1980 sonrası Türkiye'de yapılmış olan çalışmalar düşünüldügüünde Ecevit'e göre üç temel grup ortaya çıkmaktadır:

1) Kadın konusunun dışında yapılmış, ancak içinde kadınla ilgili bilgilere de yer verilmiş olan çalışmalar,

2) Kadın konusunda yapılmış, feminist bir yaklaşıma sahip olmayan ve daha çok kadının değişen statü ve konumlarıyla ilgilenen çalışmalar,

3) Kadın konusunda yapılmış, feminist bakış ve metodolojik ilkeler çerçevesinde gerçekleştirilmiş araştırmalar (Ecevit, 1996, 320).

Bu gruplama kadın çalışmaları konusundaki en azından ülkemizdeki durumu ortaya koymaktadır. Çalışmaların bir kısmı alanlarındaki mevcut yöntemleri kadın konusuna uyarlamışlar, bir kısmı ise feminist bakış açısı ile çalışmalarını gerçekleştirmişlerdir.

Yine bu gruplamadan yola çıkarak, kadınlar hakkında çok sayıda araştırma yapıldığını, ancak kadınlar "ile" ve kadınlar "için" akademik feminist araştırmanın son yıllarda yapılmaya başlandığını belirtebiliriz (Wolf, 2009, 375). Sancar'a göre, kadın çalışmaları, bir biçimde kadın sorunlarını gören, kadınları güçlendirmeye yönelik çalışmalardır. Ama feminist bakış bunun içindeki iktidar ilişkilerini gören ve esas olarak eşitsizlik yaratan iktidar ilişkilerini değiştirmeye çalışan bir perspektif oluşturur. Genellikle kadın çalışmaları feminizmle iç içe geçer ve feministleşir (Sancar ile röportaj, L. Sunar, \& M. Şentürk, 2006, 160).

Kadın çalışmaları alanının bir bilgi alanı olarak tanımlanması ve bunun akademik bir eğitim ve araştırma alanına dönüşmesi sürecinde kadın çalışmalarının kendini diğer akademik disiplinlerden farklı olarak nasıl tanımlamaya çalıştığını görmek gerekir. 1979'da Adrienne Rich bunu anlatmak için temel bir soru soruyordu: Bir kadın kendi-bilincine ve kendi kararlarına sahip bir insan olabilmek için hangi bilgilere gereksinim duyar? Kendi sansürsüz tarihini, kendi bedeninin nasıl politik bir alan, cinsel nesne veya tüketim kodu haline geldiğini, neden her yerde kadın emeğinin ücretsiz/karşılıksız ya da aynı düzeydeki erkek emeğinden her zaman daha ucuz olduğunu, neden eşit vatandaşlık haklarına sahip olamadıklarını, neden devlet, bilim, hukuk, medya ve siyaset gibi büyük 'özne’lerin bu konularda sessiz kaldığını bilmesi gerekmez mi? Bu ve benzer soruların yanıtlarını araştıracak bir bilgi alanının ve bu bilgileri öğretecek bir eğitimin oluşması kadınların kendi ortak bağlamları hakkında kendi cehaletlerinin gerilemesine yol açmaz mı? (Sancar, 2003, 165)

Bu doğrultuda Sancar'a göre kadın çalışmaları alanı kısaca kadınların nasıl ezildiği, ama 
buna rağmen nasıl varolduğu ve bununla başetmeyi nasıl becer-ebil-diği; bu mücadelelerin tarihi, yani cinsiyete dayalı ezilmenin bugüne kadar nasıl devam edebildiğini anlamaya çalışmak olarak tanımlanabilir. Sancar, akademik alanda kadın çalışmalarının ilk sahiplerinin feminist politika ve hareketten gelen aktivist kuşak olduğunu belirtmektedir. Sancar da Kandiyoti gibi, akademik disiplinler içinde bir çalışma alanı olarak kadın çalışmaları alanının ilk dönemlerde kadın ve hukuk, siyaset, eğitim, aile şeklinde konular bileşimi olarak ele alındığını belirtmektedir. Sancar'a göre disiplinlerarası olma iddiası, bir tek disiplin içinde kalmayı reddetme, bilginin parçalanıp ayrılarak ayrı ayrı kompartımanlara sokulmasına karşı çıkarak daha bütüncül bir bilgi olabileceğini göstermeye çalışmak anlamına geliyor. Yani, disiplinlerarasılık epistemolojik bir tercihtir; toplumsallığın parçalanamaz bütünselliğine gönderme yapar ve feminizmin temel bir iddiası olan- toplumsal cinsiyetin, toplumsal olguların kurucu ve anlamlandırıcı temel faktörlerden biri olduğu iddiasına dayanır. Diğer bir deyişle, toplumsallık denilen alan cinsiyete dayalı ilişkiler tarafindan baştan başa yeniden ve yeniden kurulur; bunun dışında, cinsiyetlendirilmişeril/dişil dikotomisi ile iktidarsız-landırılmış olmayan bir alan yoktur. Dolayısıyla, sosyal bilimlerin bütün disiplinleri kendi kavram ve yönteme dair araçlarını bu gözlükten bakarak yeniden ve yeniden test etmeli ve toplumsallığ , baştan sona cinsiyetlendirilmiş bir kurgu olarak -baştan sona sınıflara ayrıştırılmış bir kurgu olduğu gibi- yeniden kavramayı denemelidirler (Sancar, 2003, 170).

Kadın çalışmaları disiplinlerarası bir alan olduğu için teorik ve yöntemsel sorunlarla karşılaşmaktadır. Her disiplin kadın sorununa kendi bakış açısıyla yaklaşmaktadır. Yöntem ve teorik anlamda ortaya çıkan bu sorunlar dolayısıyla da kadın çalışmalarının kendi başına ayrı bir disiplin olması tartışmaları da gündeme gelmiştir. Kadın çalışmalarının uluslararası ve disiplinlerarası olma özelliği kuvvetlendikçe, tartışma alanları ve yaklaşımları da giderek çoğalmaktadır (Çimrin, 2006, 147-8).

Kandiyoti, bu alandaki diğer bir soruna değinerek, kadın çalışmaları alanında analizler yapılırken yaygınlık kazanmış görünen kadın merkezli alan listeleri yaklaşımından (hukuk ve kadın, ekonomi ve kadın vb.) vazgeçilmesi gerektiğini savunmaktadır. Kandiyoti’ye göre kadınları kurumsal yapılardaki görünümleri birbirlerine ekleyerek anlama çabasının bir anlamı yoktur. Bu yüzden de izlenilmesi gereken yöntem, farklı kurumsal alanlarda geçerli olan ideolojiler arasındaki gerilimlerin ve çelişkilerin ortaya konulmasından geçmektedir (Kandiyoti, 1995, 369).

\section{Modernleşme ve Pozitivist Bilim}

Modernleşmeci bilim paradigması pozitivizmdir. Batı uygarlığı dediğimiz olgunun merkezinde, tam kalbinde, bilimi ve aklı içeren iki yönlü fikir vardır. Batı uygarlığının mirasının ve onsekizinci yüzyıl Aydınlanma Çağı'nın merkezini oluşturan bilimsel bilgi fikri, kendini bütün insanlığın bir tasarısı olarak düşünmüştür. Bilim yöntemlerinin ve nesnelerinin-doğa, insan ve toplum kanunları-evrenselliği, bilimin halka özgü özelliklerinin, kişisel olmayan ve nesnel karakterinde yattı̆̆ anlamına gelmiştir (McCarthy, 2002, 159).

Pozitivist için bilim, dışsal dünyaya ilişkin kestirimci ve açıklayıcı bilgi elde etme girişimidir. Gözlem ve deney emin ve kesin ampirik bilginin tek kaynağıdır. Duyu deneyimleri ile bize ifşa edilmiş olan olayların "arkasındaki" veya "ötesindeki”ni elde etmeye çalışmak bilimin amacı değildir (Keat, \& Urry, 1994, 9).

Modern sosyal teorinin nesnel (bilimsel) bilgi modelinin dayandığı önermeler şunlardır:

a) Bilimin kavramlarının her zaman ve her yerde evrensel olarak uygulanabilir olması gerekir.

b) Bilimin işleyişi, dünyanın mevcut bilgisine ulaşmayı amaçlaması, ancak araştırmacıların dünyanın neye benzemesi gerektiği konusundaki düşüncelerini dikkate almaması anlaminda, nesnel olmalıdır.

c) Bu yüzden, araştırmacıların kişisel özellikleri ile oluşturdukları bilgi iddialarının de- 
ğerlendirilmesi arasında bir ilişki olmamalı ve bilimsel kurumlar bunu sağlayacak biçimde tasarlanmalıdır.

d) Rakip bilgi iddialarının değerlendirileceği standartlar veya kriterler evrensel ve bu yüzden, rakip konumları değerlendirecek ölçüde tarafsız olmalıdır (Benton, \& Craib, 2008, 179).

Pozitivist bilim, değerlerden arınmış nesnellik kabulüne dayanır; bilimci ya da sosyal bilimci "olguları" ya da "hakikati" arar ve ortaya çıkarırken değerden arınmış bir nesnellik takınabilir, takınması gerekir ve takınmalıdır. Araştırmanın başkaları tarafından tamamıyle tekrar edilebilir olması gerekir ve bu girişimin, evrensel hakikatler hakkındaki bilgimizi arttırdığg düşünülür. Bu bilim yaklaşımı, araştırmacı ile araştırılan arasında mesafe ve katılımsızlık yaratır ve teşvik eder; araştırmacının, öznelerinin hayatını ve anlamlarını nesnel olarak görebileceğini, yargılayabileceğini ve yorumlayabileceğini varsayar (Wolf, 2009, 377).

Toplumbilimsel araştırma yöntemlerinde geleneksel olarak iki eğilim gözlenmektedir: Rasyonalizm ve Ampirizm. Geleneksel yaklaşımın varsayımları şunlardır:

1) Toplumsal dünya nesnel olarak ölçülebilir. Gözlemleme ve kayıt etme araştırmacı öznelliğinden bağımsız bir nesnelliği sağlar.

2) Nesnellik ve öznellik birbirinden ayrılabilir. Araştırmacının öznelliği, araştırmanın nesnelliğini bozmaz.

3) Toplumsal dünya, aklın kullanımına dayalıdır, bu nedenle insan davranışına ilişkin doğru ve güvenilir bilgi elde edilebilir.

4) Toplumsal dünya modellenebilir ve bu model temel olarak neden sonuç ilişkisiyle biçimlenir.

5) Dünyayı anlamak için bütün bilim dallarının aynı yöntemi kullanmaları gereklidir. $\mathrm{Bu}$ aynı zamanda bilgi derlemenin meşruluğunu sağlar (Karaduman, 2006, 89-93).

Modernleşme düşüncesi, ilerlemeci, evrimci, evrenselci, batı merkezci, özcü ve indirgemeci, düalist niteliğe sahiptir. Bu özellikleri kadın konusunda da büyük anlatılar ve evrenselci açıklamalar şeklinde kendini göstermektedir.

Kadın veya feminist araştırmalar için gerekli bir metodoloji yolunu açan düşünceler egemen sosyal bilime yönelik eleştiri dalgasının çevresinde gelişen çeşitli tartışmalardan doğdu ve gelişti. Çünkü pozitivizm, özne ile nesne arasındaki ilişkileri sorunsallaştırmak istemiyordu. Epistemoloji yalnızca bilgi içerikleriyle uğraşmalı, bilgi içeriklerini ortaya atan öznelerin düşünce ve inançlarıyla ilgilenmemeliydi. Gerçek dünya irdelenirken, öğrenilen bilgi içeriğine özne mümkün olduğunca az katılmalıydı. Pozitivizmin bilim felsefesindeki egemenliği 20. yüzyılda azalmaya başladı (Çakır, 1996, 305-316).

\section{Pozitivizmin Feminist Eleştirisi}

Gorelick, pozitivizme yönelik feminist eleştirileri üç noktada (felsefi, moral-ahlaki ve pratik düzeyde) ele almaktadır:

1) Felsefi düzeyde pozitivizmin eleştirisi olarak: Değerden arınmış bilim ve nesnellik varsayımının varlığının tasavvur edilmesinin, bilimin bir süreçten çok bir başarı ya da işlemler dizisi olarak ele alınmasının eleştirisi, 2) Ahlaki düzeyde: Feministler, öznelerin nesneleştirilmesini ve başat metodlar kullanarak onların sömürülmesini eleştirmişlerdir. Nesneleştirme, bilimci ile öznesi arasında radikal bir fark gözetmesine dayanır. Feminizm, sosyolojide yorumlayıcı yaklaşım üzerine inşa edilir. Bilim üretimi bir operasyon değil, bir ilişkidir. 3) Araştırma hiyerarşisinin moral eleştirisi, başat metodolojilerin pratik eleştirisi ile ilgilidir. Başat hiyerarşik metodolojik yaklaşımlar içinde araştıran ve araştırılanın karşıt çıkarlara sahip olduğuna ilişkin görüş feministler tarafından eleştirilir (Gorelick, 1991, 460).

$\mathrm{Bu}$ eşit olmayan ilişki, sosyal bilimlerde zamanla sorunsallaştırılmış, kadınların ve cinsel 
yönelim azınlıklarının heteroseksüel-erkek egemen bakış açısıyla yürütülen bu tür araştırmalarda, yeterince temsil edilmedikleri ve hatta görünmez k1lındıkları tezleri ortaya atılmıştır. Bu eleştiriler sonucunda belirginleşen ikinci dönemde, kadın ve cinsel tercihleri heteroseksüellik olmayan gruplara mensup araştırmacıların, kendi ait oldukları sınıflar, etnik gruplar ile cinsel yönelim azınlıkları veya baskın grupları ilgilendiren konulardaki araştırmalarda söz sahibi olmaya başlamaları, araştırmacı-katılımcı ilişkisinde demokratikleşme ve eşitlik sürecinin başlangıcı olmuştur. 1980'lerin başlarından itibaren, yukarıda sözü edilen araştırmalardaki güç dengesizlikleri ve etik sorunlar Shapiro (1981), Kelley (1987), Wilson (1987) ve Nielsen (1990) gibi yazarlar tarafından tartışılmıştır. Bu dönemde gelişen kadın çalışmaları, toplumsal cinsiyet ve cinsellik üzerine araştırmalar, kadınların ve cinsel yönelim azınlıklarının yakın zamana dek konuşulmayan ensest, aile içi şiddet, taciz ve ayrımcılık sorunlarını sosyal bilimlerin konuları arasına katmışlardır. Antropolojik araştırmalar, kadın araştırmacıların hemcinsleriyle daha kolay ilişki kurabildiğini, özellikle batılı kentli kadının özel alandaki sorunlarını kadın araştırmacılarla daha rahat paylaşabildiğini ortaya koymuştur. Kadın araştırmacıların, ortak kadınlık deneyimleri ve değerleri nedeniyle kadın katılımcıların deneyimlerini daha kolay anlayabilecekleri tezi sıkça savunulmuştur. Bu yaklaşım, kadın ve erkek araştırmacıların kendi hemcinslerinin deneyimlerini ortak cinsiyet deneyimleri nedeni ile daha iyi anlayabileceklerinin altını çizmiştir. Bu demokratikleşme yönelimi doğrultusunda, araştırma terminolojisi bir değişime uğramış ve katılımcılık kavramı sosyal bilimler içinde giderek benimsenmiştir (Aliefendioğlu, \& Özbilgin, 2001).

Yerleşik sosyal bilim metodolojisine feminist kuramcıların yönelttiği temel eleştiri, mevcut bilimlerin erkek bakış açısının bir sonucu olduğu ve dolayısıyla kadın deneyimini hesaba katmadığı noktasındadır. Bu eleştiriye göre, insan bilgisi büyük oranda deneyim üzerine kurulmaktadır. Kuşkusuz insan deneyimi; kişilerin giriştikleri eylem, içinde bulundukları sosyal bağlam ve kurdukları ilişkilerin türüne göre farklılaşmaktadır. Bu çerçevede feministlere göre, tarihsel olarak kadınların deneyimleri erkeklerinkilerden sistematik biçimde farklılaşma göstermektedir. Yerleşik kurumsal nitelik taşıyan bilgiler, insan deneyiminin sadece bir bölümünü, yani erkeklerin deneyimini içermektedir. Feministlere göre, bunların insanlığın ortak deneyimi olarak kabul edilmesi, hem insan bilgisi hem de sosyal hayat üzerinde tahrip edici sonuçlar yaratmaktadır (Demir, 2012, 172).

$\mathrm{Bu}$ genel çerçeve içinde, modern yerleşik bilim anlayış ve uygulamalarına yöneltilen feminist eleştirileri dört grupta toplamak mümkündür: İlk eleştiri bilim politikası ile ilgilidir. Buna göre, bütün bilim dallarında erkekler kadınlardan daha çok eğitilmekte ve istihdam edilmektedir. Gerek doğa bilimleri gerekse sosyal bilimlerde, bilim kadınlarının sayısı erkekler ile kıyaslandığında görece olarak oldukça sınırlıdır. Kadınların bilim topluluklarındaki azınlık durumları, bilimsel kurum ve organizasyonların erkekler tarafından biçimlendirilmesi ve yönlendirilmesi sonucunu getirmektedir. Bu da bilimsel çalışmalarda, doğrudan kadınları ilgilendiren konuların önemsenmemesine yol açmaktadır. Daha radikal olan ikinci eleştiri, gerek konuların seçiminde, gerekse deney-gözlemlerin tasarlanması ve tanımlanmasında, kadınlar aleyhine bir taraflılığın olduğunu ileri sürmekte ve tarafsız bilim adı altında erkek egemen sorun tanımları ile açıklama biçimlerinin mevcut bilim anlayışına hakim olduğunu savunmaktadır. Üçüncü eleştiri; kadın erkek ilişkilerinde kadınların ikincilleştirilmesine hizmet eden öznel/nesnel, akı1/duygu, zihin/beden, olgu/değer, kamu/özel, birey/toplum gibi ikilemlerin, bilimsel açıklamalarda temel alınmasının yarattığı sorunları konu edinmektedir. Son feminist eleştiri ise; modern bilimi karakterize eden nesnellik, tarafsızlık ve rasyonellik varsayımlarının erkek egemen içerimlerini sorgulamaktadır (Demir, 2012, 172-73).

Demir'in vurguladığı bilimsel çalışmada kadınların önemsenmemesi ile ilgili bir örnek, psikoloji ve tıptan verilmiştir. Psikolojik ve insan gelişimi hakkında bildiğimizi sandığımız şeyler aslında erkeklerin gelişimine özel bilgi olmuştur. Örneğin göğüs kanseri ve kadın kalp hastalık- 
ları oranlarının yüksek oluşu göz önünde bulundurulduğunda, bunların nedenleri ve tedavileri konusunda görece olarak çok az şey bilinmekteydi (Mccarthy, 2002, 168). Bunun karşısında yer alan feminist bilimin amacı ise bilimsel bilginin nesnelliğini en üst düzeye çıkarmak ve kadınların yaşamlarından da yararlanmaktı.

Pozitivizme özellikle değerlerden arınmışlık ve nesnellik konularında eleştiriler yöneltilmeye başlandı. Feminist bilgi eleştirisi de bu noktada gündeme geldi. Kadınların sorguladıkları ilk şey, bilimin objektifliği ve evrenselliği ile erkek önyargısı ve erkek merkezciliği kavramları oldu. Kadın çalışmalarının yüzyüze olduğu en önemli problem, hemen hemen bütün disiplinlerde erkek önyarg1s1 ve erkek merkezciliktir. Bilgiye ulaşmada kullanılan yöntemler ve objektiflik denilen kavram, erkek bakış açısını yansıtır. Bu durum özellikle kadınların tarihinin olmamasında ortaya çıktı. Kadınlar hakkında niçin bilgi yoktu? Geleneksel tarih yazıcılığının yapısı, tarih bilimcilerinin çok azının kadın olması, tarihi erkeklerin yazması, kendi pratiklerinden kaynaklanan olayları konu etmeleri kadınların tarih içindeki deneyimlerini görünmez kılar. Sosyoloji, ekonomi gibi bilimlerde de durum buna benzerdi. Kadınları görünür kılmanın önündeki en önemli engel sosyal bilimler metodolojisiydi. Tüm bunlar kadın araştırmalarında yöntem sorununu gündeme getirdi ve şu sorulara yanıt aranmaya başlandı: Feminist araştırma yöntemini geleneksel yöntemlerden farklılaştıran nedir? Feministler geleneksel araştırma yöntemleri ve tekniklerine ve bunlardan hareketle oluşturulan bulgulara ne tür eleştiriler getiriyor? Sınırları belirlenmiş bir feminist araştırma yöntemi var mıdır? Feminist araştırma sürecinde araştırmacı-araştıran ilişkisi nasıldır? Bu süreçte bir deneyim olarak duygunun önemi nedir? (Çakır, 1996, 309).

$\mathrm{Bu}$ ve buna benzer sorular sosyal bilimlerde mevcut bilgilere feminist bakış açısının ilave edilmesini de beraberinde getirdi. Eğer kadın çalışmaları, kadınların özgürlüğü için bir araç olarak kullanılacaksa pozitivist, niceliksel araştırma metodolojisini eleştirmesi gerekir. Mies'in deyişiyle "yeni şarap eski şişelere doldurulmamalıdır". Feminist teori, feministlerin sorgulamalarıyla analitik açıdan güçlendirilen, deneyimlere dayalı, deneyimin ışığında sürekli gözden geçirilen, dönüşümsel ve özdüşünümsel ve herkes için erişilebilir olan, sadece özel kişiler olarak teorisyenlere açık olmayan, sürekli yeniden yorumlanan, didiklenen, "metinler'deki gibi eleştiriüstü ve kutsal görülmeyecek bir teori" olarak anlaş1lmalıdır (Çakır, 1996, 312).

Benzer bir görüş Marshall tarafından da dile getirilmiştir. Marshall, sözlüğünde, feminist sosyal bilimin (ya da genel olarak sosyal bilimlerin, hatta genel olarak bilimin) yeni bir metodolojiye gereksinim duyduğunu öne süren bir dizi öneri yapıldığını belirtmektedir. Bunlardan bazıları araştırma tasarımı, bazıları epistemoloji ve bazıları ontolojiyle ilgilidir. Feminist araştırma yöntemlerine dair öneriler, ya araştırmadaki bilinçsiz cinsiyetçi eğilimin (bu durumda erkek bakış açısı ve çifte standart olduğu kabul edilir) ortadan kaldırılmasına ya da sözde nesnel biçimde yapılandırılmış görüşmelerin ve kantitatif çözümlemelerin, daha düşünümsel, etkileşimli, yapılandırılmamış görüşmeler ve öznelerin kendileri hakkında konuşmalarına olanak tanıyan bir sosyoloji yazım yöntemiyle değiştirilmesine yöneliktir. Epistemolojik terimlerle ifade edecek olursak, nesnellik, hakikat ve doğanın denetimi arayışında olan bir görüş, erkeksi bir tutkudur; kadınların bilen ile bilinen, benlik ile öteki, zihin ile beden, özne ile nesne arasında daha az ayrım yaptıkları ve belirsizlikle çok sayıda hakikat konusunda daha hoşgörülü oldukları düşünülür. "Feminist duruş noktası" (standpoint kavramı bazı eserlerde bakış açısı, bazılarında görüş açısı, bazılarında da duruş noktası olarak çevrilmiş̧tir) ndaki bir diğer etkin fikir ise, tabi kılınmış bir grup olarak kadınların, toplumsal gerçekliğin yeterince temsil edilmesi konusunda -kendi denetim projelerine takılıp kalmış olan- erkeklerden daha iyi konumda olduklarıdır. Bu epistemolojik avantaj, kadınların şu anda varolan inançları ve tutumlarında zorunlu olarak yansıtılamaz, bunun sağlanması için feminist temelde bir gayret ve analize ihtiyaç vardır. $\mathrm{Bu}$, akılcı seçimler yapan izole edilmiş bireylerin soyut nosyonlarıla çalışmaktan ziyade, yeniden üretim, bedensel çalışma ve mahrem ilişkileri (ki bunlar kadınların gündelik varoluşlarının somut 
gerçeklikleridir) içeren bir toplumu anlama sürecini sağlayacaktır. "Duruş noktası" konumu feminizmin, erkeksi bilimden daha doğru bir gerçeklik resmi ortaya koymasının mümkün olduğuna inanır. Dolayısıyla ontolojiye göre böylesi bir duruş gerçekçi bir konumdur. Yani bu yaklaşım, tüm bilimsel nesnellik iddialarına karşı şüpheci yaklaşan feminist postmodernizmden farklılaşır, tüm bilgiyi, özel tarihsel ve sınırlı durumlarda üretilmiş bir şey olarak görür ve kadınlarla erkekler arasında olduğu gibi, kadınların kendi aralarında da önemli farklılıklar (ırk, sınıf, etnisite ve cinsel yönelim gibi) bulunduğunu kabul eder (Marshall, 1999, 239-241).

25 yıl önce Kanadalı feminist filozof Lorraine Code, "Bilen kişinin cinsiyeti epistemolojik olarak önemli mi?" diye sorarak ana akım bilgi felsefesinden farklı bir feminist epistemolojinin nedenlerini açıklamaya başladı. L. Code, 1970'lerde bilgiyi yaratmada erkeklik, güç ve otorite gibi konularla ilgilenmeye başlayan çoğu feministten sadece biridir. Bu sorgulama pek çok disiplinde yapılmaktadır (Doucet, \& Mauthner, 2007, 36). Yine Code'a göre, feminist bilgi teorileri ve feminist bilgi inşası, standart bilgi teorisi içindeki toplumsal cinsiyetin nötrlüğüne ilişkin ön kabule meydan okuma üzerine oluşturulmuştur (Ritzer, 2005, 271-274).

Feministlerin ve postampiristlerin savunduğu, özellikle toplumbilimlerinde nesnel ve değerlerden arınmış olunamayacağıdır. Harding, geleneksel toplumbilim araştırmalarında, kavramlaştırmanın erkek deneyimini yansıttığını, araştırmalarda toplumsal yaşamda erkekler açısından sorun olduğu düşünülen olguların soruya dönüştürüldüğünü belirtmektedir. Harding'e göre, araştırmalarda birçok olgu tipik erkek deneyimi sonucu sorun olarak tanımlanmakta, tipik kadın deneyimi sonucunda sorun olarak tanımlanan olgular ise görünmez kılınmaktadır. Kadın deneyimini önemseyen yeni bir analiz geleneği toplumsal yaşamın tümünü etkileyecek güçtedir ve bu araştırmacılara yeni kaynaklar săglayacaktır (Karaduman, 2006, 88-93).

Cancian (1992, 623-642), feminist hedeflerin geleneksel pozitivist yöntemlere uyup uymadığını tartıştığ1 makalesinde, bu konuda iki görüş olduğunu belirtmektedir. Feminist yöntemleri savunan akademisyenler, pozitivist yöntemlere şüphe ile yaklaşırlar. Feministler, bu geleneksel, izole ve değer yargısız yöntemlerin, aslında bazı uzman ve elitlerin egemenliği olarak görürler. Feminist akademisyenler ise, kadın deneyimleri ve cinsiyetçi baskıya savaş odaklı bir yöntem önerirler. Cancian feministlerin kendine özgü bir feminist metodoloji kullanmaları gerektiğini savunmaktadır. Ona göre geleneksel metodlar eşitsizliği pekiştirmektedir. Feminist metodlar ise eşitsizlikle mücadele ve kadının özgürleştirilmesi gibi hedeflerle uyuşmaktadır. Bu bakış açısını anlamak için sosyal inşa veya sosyal pratik gibi perspektifleri kullanmalıyız. Bu bakış açısına göre bilim, belli grupların sosyal aktivitesidir ve bilimsel sonuçlar, grupların değer yargılarına, geçmişlerine ve sosyal konumlarına göre şekillenir. Sosyal pratik perspektifine göre her metodoloji belli araştırmacı grupların ilgi ve konumlarına göre şekillenir.

Araştırma yöntemleriyle ilgili tartışmaların başka bir boyutu, araştırmaya konu olan, araştırma sorularını cevaplayan kişilerle ilgilidir. Araştırmacı (özne) ve araştırılan (nesne) arasındaki hiyerarşik ilişki, tartışmaların başlıca konusudur. Feminist araştırmacılara göre, kadınların toplumsal bilginin sadece nesneleri değil, aynı zamanda öznesi olduğu yerlerde özne ve nesne, bilen ve bilinen arasındaki ayrım son bulur. Böylece kadın olmanın ortak koşullarını paylaşan iki insanın, yani araştırmacının kendisi ile "öteki kadın”ın karmaşık bazı deneyimleri ortaya ç1karma olanakları artar (Karaduman, 2006, 88-93).

Kültürel çalışmaların ve feminist araştırmaların entelektüel ve politik gelişimlerini oluşturan en önemli ortak unsur, marjinalleştirilmiş ve sessizleştirilmiş grupları araştırma konuları olarak ele almasıdır. Feministler, kendi deneyimlerinden yola çıkarak ataerkil toplumun ve kültürün kadınlara nasıl sistematik bir biçimde baskı uyguladığını incelediler. Hakim kültürün ürettiği bilgilerin meşruluğunu sorguladılar. Feminist araştırmalar ve kültürel çalışmalar, iktidarın ve eşitsizliğin biçimlerini ve uygulamalarını inceler ve bilgi üretimini bu uygulamaların merkezine oturtur; post yapısalcı, psikanaliz, semiyoloji, yapıbozum yöntemlerini ve söylem kuramını kul- 
lanarak, eleştirel yaklaşımla toplumsal eşitsizliklerin yeniden üretimini, egemen ve tabi gruplar arasındaki ilişkiyi inceler. Yeni analitik yöntemler geliştirilmesine zemin oluşturan bu kuram ve yöntemleri kullanan araştırmacılar, her iki alanda "güç ve direnme" kuramlarının daha da güçlenmesini sağladı (Kırca, 2001, 25-31).

Sosyal bilimlerdeki feminist araştırmanın dönüştürücü gücüne en çarpıcı biçimde 1960'ların sonlarında sosyolojide tanık olundu. Bilginin bir toplumsal cinsiyet meselesi olup olmayacağ feminist epistemolojinin mümkün olup olmadığı sorgulanmaya başlandı. Sandra Harding, üç feminist yaklaşım ayrımı yapmak gerektiğini belirtiyor: Feminist empirizm, feminist bakış açısı (standpoint) epistemolojisi ve feminist postmodernizm. Harding'e göre feminist empirizm, doğa veya sosyal bilim araştırmalarına yönelen feministlerin konumudur. $\mathrm{Bu}$ feministler bilimin kadınları yanlış sunduğunu ve yanlış ele aldığını kabul eder, ancak bunun esasında bilim için önemli olmadığına inanırlar. Feminist bakış açısı epistemolojisinin önemli temsilcilerinden Nancy Hartstock'a göre, feminist bakış açısı epistemolojisi üç evrede yapılandırılır: Birinci evrede, kadınlar toplumdaki genel işbölümü içinde özel bir konum işgal etmektedir. İkinci evrede, bu durumun dünyayı bilme ve yaşamanın feminist temelinin nasıl oluşturulabileceği gösterilir. Üçüncü evrede, feminist bilginin güvenilir bir bilgi olduğunu göstermeyi gerektirir. Kadınların toplumsal işbölümü içindeki yerlerine bağlı olarak farklı bilme biçimleri vardır. Feminist epistemoloji geleneksel epistemolojilere büyük ölçüde benzemektedir, ancak onların kavrayamayacağı görüşler ve reform imkanları sunmaktadır (Benton, \& Craib, 2008, 186-200).

Dorothy Smith'in feminist görüş açısı (standpoint) kuramı, hem toplumsal hem de toplumsal-psikolojik ögeler içermektedir. Smith, kadın bakış açısı üzerine odaklanmışsa da Patricia Hill Collins tarafindan çözümlenmiş olan siyah kadınlar, ikincil durumda olan başka bireyler, yoksul beyaz kadın ve erkekler, homoseksüel kadın ve erkekler, çağdaş Batı toplumunun dışındaki azınlık etnik ve dinsel gruplar üzerinde durur. Smith, kadınlarca günlük deneyimlerinde yaşanan erkek egemen yapılar ve kadınların bu deneyimler hakkındaki düşünceleri ve duyguları ile ilgilenir. Dorothy Smith'in bu çalışmasının amacı açısından önemi şu sözlerinde ortaya çıkmaktadır: "Kendi çalışmalarım, bir toplayıcı kuram değil, daima ileriye doğru devam eden, her şeyin iç yüzünü araştıran, keşfeden, ister kadınların, ister diğer ezilen gruplartn giderek gelişen mücadelesi ile ilgili politika ve uygulamalarına dönük bir araştırma yöntemidir." $\mathrm{Bu}$ anlamda D. Smith, geniş ölçüde eleştirel çatışma yaklaşımından faydalanmakta ve fenomenoloji metodolojisinin ötesine geçmektedir. Ona göre araştırmanın dönüştürücü yönelimi de olmalıdır. Bilen özne, her zaman, belirli bir yer ve zaman içinde hayatın belli bir kısmı içinde bulunmaktadır. Araştırma, onun bilmediğinin araştırılması ve açıklanmasına yöneliktir (Wallace, \& Wolf, 2004, 339). Kısaca D. Smith, feminist eleştiri içinde salt kadın üzerinde odaklanmayıp tüm diğer ikincil konumdakileri araştırmakta ve araştırmanın temel misyonunun dönüştürme olduğunu vurgulamaktadır.

Feminizmin gördüğü işlev ve uğradığı dönüşümle ilgili iki gelişmeye dikkat çeken Demir'e göre, modernizm ve postmodernizm ile feminizm ilişkisi de farklı kurulmaktadır. Modernizmin en önemli tezlerinden biri, kadınları geleneksel ilişkiler dünyasındaki ikincillikten kurtarma vaadidir. Bu çerçevede eğitim, sağlık, sosyal güvenlik ve çalışma imkanlarının kadınları da içine alacak biçimde genişletilmesi ya da seçme ve seçilme hakkı gibi siyasal hakların kadınlara da verilmesi, en popüler ve destek bulan hedeflerdi. Buna karşlık bugün feminizm, modern projenin sunduğu insan kategorisinin ve bu kategori merkezinde dünyaya ilişkin açıklamaları, insanların tümünün bakış açısını yansıtmak anlamında evrensel olmadığını, sadece erkeklerin-batılı, orta sınıf ve beyaz-gözüyle çizilmiş bir proje olduğunu ileri sürerek, toptan ve temelden eleştirmektedir. Böyle bir eleştiri, neredeyse feminizmi ortaya çıaran bu iktisadi ve sosyal gelişmelerin yadsınması anlamına gelmektedir. Modernizme eleştiriler getiren feminizm, postmodern feminizm olarak dönüşüme uğramaktadır. Postmodern feministlere göre, kadın erkek ikilemine dayalı olarak 
üretilen erkek egemen kültür veya patriarki gibi büyük anlatılar kurma, böylece kadın-erkek sorununu çözme ideali de modernist bir nitelik taşımaktadır. Bu yüzden feminizm, tektip ve homojen bir bilgi kümesini değil, modern-postmodern ayrımının içinde daha alt ayrımlarla kategorize edilebilecek ve liberalinden radikaline, marksistinden sosyalistine, varoluşçusundan yapısalcısına kadar birçok versiyonu olan-çoğulcu bir bilgi kümesini nitelemektedir (Demir, 2012, 173-74). Feminizm, modernizmin bilgi teorisine eleştiri getirmesine karşın, özünde bir büyük anlatı barındırdığı için postmodern bir çerçevede temellendirilemez. Çünkü postmodernizm, tüm diğer büyük anlatıları olduğu gibi feminizmi de, kullandığı analitik kavramların bile sonunda indirgemeci sonuçlar doğuracağı gerekçesiyle eleştirmektedir. Ancak hem postmodernizmi hem feminizmi dönüştürerek postmodern bir feminizmin mümkün olabileceğini savunan düşünürlere göre bu iki yaklaşım arasında şu benzerlikler vardır: Hem postmodernizm hem de feminizm felsefe kurumunu derin ve kapsamlı olarak eleştirmişlerdir. Her ikisi de felsefe ve daha geniş kültür arasındaki ilişki üzerinde eleştirel bakış açıları geliştirmişlerdir. Her ikisi de toplumsal eleştiri paradigmaları geliştirmeye çalışmışlardır (Fraser, \& Nicholson, 1994, 276). Feminizmde yöntem tartışmaları açısından, postmodernist feminizmin getirdiği araçlara bakıldığında, özellikle postyapısalcılıktan uçlanan dört kavram karşımıza çıkmaktadır: Bunlar dil, söylem, farklılık ve yapıçözümüdür. Feminist yaklaşım dil çözümlemesini üç biçimde kullanmaktadır: 1) Kadın ve erkeğin nitelik ve özelliklerinin metinlerde nasıl dile getirildiğinin çözümlenmesi üzerine odaklaşmak. 2) Kadın ve erkeklere ilişkin kültürel tipleme ve söylemlerin nasıl ikilemler biçiminde ele alındığını incelemek. 3) Bilinçli ya da bilinçsiz bir biçimde yerleşmiş bulunan toplumsal cinsiyet ilişkilerinin retorik yoluyla nasıl kullanıldığını ortaya koymak (Demir, 1997, 103). Özellikle üç Fransız feminist düşünür (Kristeva, Irigaray ve Cixous) kadının ikincil durumunun somut ekonomik, siyasal ve sosyal yapılardan değil, dilin kendisinden kaynaklandığını iddia etmektedir. Buna göre anlam sistemi, dilsel ve mantıksal örüntüler içinde kadınlık konusunda belli bir mantıksal anlam yükleyerek kadınların konumunu ikincilleştirmektedir. Toplumsal ilişkilere egemen olan erkek merkezli ve erkek egemenliğine dayalı yapı, dil yoluyla sürekli yeniden üretilmekte ve sonraki kuşaklara iletilmektedir. Kısacası postmodernizm, postmodern feminizme, söz merkezciliğin eleştirisi, farklılıkların, yerelliklerin ve özgüllüklerin önemi, yapıçözümcülüğün sosyal bilimlere uygulanması, çoklu söylemlerin kabul edilmesi ve öznelliğin vurgulanması gibi konularda temel oluşturmuştur (Demir, 1997, 113).

Pozitivizmin feminist eleştirisi, postmodernist düşünceden de etkilenmiş ve feminizm, beraberinde aşağıda belirteceğimiz eleştirel bir araştırma metodolojisini getirmiştir.

\section{Feminist Metodoloji Neler Öneriyor?}

Cook ve Fonow, sosyoloji alanında feminist metodolojinin 5 temel ilkesinin var olduğunu belirtmektedir:

1) Tüm sosyal yaşamın temel özelliği olarak toplumsal cinsiyet ve toplumsal cinsiyet asimetrisinin önemini sürekli ve düşünümsel olarak göz önüne alma zorunluluğu,

2) Bir "görme biçimi" ve genel bir yönelim olarak ve metodolojik bir araç olarak bilinç geliştirmenin önemi,

3) Bireysel deneyimlerin bilimsel olmadığı, araştırmanın özne ve nesnesinin birbirinden ayrı tutulabileceğini varsayan nesnellik normuna meydan okuma gerekliliği,

4) Bilginin nesneleri olarak kadınların sömürüldügünün kabul edilmesi ve feminist araştırma için ahlaki ilkelerin göz önüne alınması,

5) Araştırma vasıtasıyla, ataerkil sosyal kurumların dönüştürülmesi ve kadınların güçlendirilmesinin vurgulanmas1 (Cook, \& Fonow, 1986, 5).

Cancian'a göre pozitivistler kişisel deneyim ve gündelik bilgiye değer vermezler. Feminist metodoloji güç eşitsizliğine karşı çıkar, marjinal kişileri ve kadınları güçlendirir (Cancian, 1992, 623-642). 
Cancian, esasında Cook ve Fonow'a ait olan kategorileri kendi yorum ve düşünceleriyle birleştirerek feminist araştırmanın üzerinde durduğu kavramları ele almıştır. Ona göre feminist araştırmanın en belirgin özelliği toplumsal cinsiyet ve cinsler arasındaki "eşitsizliği" araştırmasıdır. Feministlere göre erkekler ve ataerkil düzen tarafından kadınlar üzerinde geniş bir baskı vardır, bu baskı doğal veya değişmez değildir. Ayrıca bu bakış açısı ırk ve sınıf gibi çeşitli eşitsizlikleri de kapsar. Bu teorik varsayımlar eşitsizliği azaltmaya yönelik güçlü bir politik ve etik kararlılık içerir. Birçok feminist araştırma, kadınların günlük "deneyimlerini" anlatır. Mülakat ve etnografi teknikleriyle kadınların duygu ve davranışlarını, geleneksel araştırmanın tersine, onaylar. Burada amaç, insanların deneyimlerine "ses" vermektir, onları doğru bir şekilde yansıtabilmektir. "Aktivizm" kavramı da önemlidir. Genellikle feminist araştırma, sosyal yapıyı değiştirici hareketler ve politikalar içerir. Buna kadınlar için araştırma denir. Feminist araştırma "eleştireldir". Araştırma evresinin, araştırmacının toplumsal cinsiyeti, ırkı, sınıfı ve cinsel oryantasyonundan etkilendiğini, böyle şekillendiğini savunur. Geleneksel araştırma yöntemlerini eleştirir. Feministler, araştırmacı ve araştııılan ayrımını reddeder ve araştırılana da güç veren "katılımcı metodları" tercih ederler. Örneğin, klasik mülakat tekniği yerine karş1lıklı interaktif bir mülakatı tercih ederler. Cancian, makalesinde boşanmış kadın ve erkeklere, heteroseksüel çiftlere ve feminist sağlık topluluğundaki katılımcılara uygulanan interaktif yöntemin sağladığ 1 faydalardan da söz etmektedir (Cancian, 1992, 623-642).

Marie Mies, feminist bir araştırma için metodolojik ilkeleri şu şekilde ele almıştır:

1) Değerden arınmış araştırma önermesi, araştırma nesnelerine karşı tarafsızlık ve kayıtsızlık ilkesi yerine, araştırma nesneleri ile kısmen yan tutan, kısmi özdeşleşmeyle gerçekleştirilen "bilinçli tarafllık" benimsenmelidir. Burada Sandra Harding'in "kesin olan şey ister kadın ister erkek olsun, günlük yaşamda kadın sömürüsüne etkin bir biçimde karşı çıkmayan bir kişinin cinsiyetçilik ve erkek merkezliliği tarafindan çarpıtılmamış herhangi bir konudaki toplumsal araştırmayı yapamayacağı gerçeğidir " düşüncesini de hatırlamak gerekir.

2) Araştırmacı ve araştırma nesneleri arasındaki dikey ilişki ve yukarıdan bakış, yerini aşağıdan bakışa bırakmalıdır.

3) Salt düşünmeye dayalı, katılımsız "seyirci bilgisi", kadının kurtuluşu için yerini eylemlerde, hareketlerde ve mücadelelerde aktif katılıma bırakmalıdır.

4) Kadınların ezilmesi ve sömürülmesine karşı çıkmak, ataerkil sistemi anlamak için başlangıçtır.

5) Araştırma süreci hem araştırma özneleri sosyal bilimciler, hem de araştırma nesneleri (hedef gruplar olarak kadınlar) için bir bilinçlenme süreci olarak yaşanır.

6) Kadınların problem-formülasyonu metodolojisi ile kolektif bir iç sorgulama yapmaları, kadınların bireysel ve sosyal tarihlerinin incelenmesiyle yan yana gitmelidir.

7) Kadınlar kendi deneyimlerini kolektifleştirmeye başlamadıkça, kendi tarihlerine sahip çıkamazlar (Mies, 1995, 48-64).

M. Mies'in değindiği kadın tarihinin yazılması konusunda sözlü tarih önemli bir araştırma yöntemi olarak ortaya çıkmaktadır. Sözlü tarih, belirli bir olayı, bir zaman dilimini, özelliklerini, bir oluşumu, o dönemde yaşamış kişilerin tanıklıklarına başvurarak inceleme, bilgi alma yöntemidir (Çakır, 1995, 226).

Feminist katılımcı araştırma, araştırmacı-araştırılan arasındaki ayrımın ortadan kaldırılması ile araştırmacıyı kontrol etme duygusundan uzaklaşarak, açıklık, karşılıklı alışveriş, karşılıklı paylaşabilme değerlerine dayanır. "Etkileşimci yöntem" olarak bilinen tekniklerden yararlanarak, araştırılanı, araştırma sürecinin önemli bir ögesi kılmak hedeflenir. Toplumu daha eşitlikçi hale getirmek nasıl mümkündür, sosyal gerçekliği anlamak ve dönüştürmekte çözüm getirici yollar nasıl sağlanır, temel sorularından yola çıkılır. Böylece araştırmacı bilginin yardım edici biçimde 
dağılımında araçsal olarak kullanılmasından sorumlu tutulur (Reinharz, 1992'den aktaran Kümbetoğlu, 2005, 59). Boşanma konusunda yapılan araştırmada, kadınlara araştırma süresince kazandırılacak bilgi ve diğer kadınların deneyimleri, kendi sorunlarının çözümü için uygun yollar bulmalarına yardımcı olabilir. Kümbetoğlu'na göre bu amacı yerine getiren yöntem, niteliksel yöntemdir. Niteliksel yöntemin kadın çalışmaları açısından önemi, kadın deneyimlerini tam olarak ve kendi ifadeleri ile sunmasındadır. Feminist araştırma ilkeleri doğrultusunda niteliksel yöntem, araştırılan ile araştırmacı arasında hiyerarşik olmayan insan ilişkisine dayanır. Bu yapı, toplanan sosyal olguların (verilerin) sayılara dökülmesinden daha çok, araştırmacı ve araştırılanın birbirlerini ve bir diğerinin hayatını, farklılığını, çeşitliliğini kabul edip anlama çabasına göre belirir. Feminist araştırmalarda kadın yaşamları incelenirken araştırmacıların kendilerini kadın gruplarının üzerinde yönlendirici, kontrol edici, otoriter bir konuma yerleştirmemeleri, sadece araştırma gündemine bağlı kalmamaları, araştırma katılımcılarının ve araştırmacının aktif rolleri ile araştırma sürecinin her iki taraf için de bilgi edinme, anlama, açıklama deneyimlerini içermesinin gerekliliği savunulmaktadır. Bu noktada araştırmacının hangi yöntemi kullandığından çok, bu yöntemi nasıl ve ne için kullandığı önemli olmaktadır (Kümbetoğlu, 2005, 61-68).

Ewick, araştırma yöntemleri derslerini veren akademisyenler açısından, pozitivist bilim üretme geleneğine ilave olarak feminist bilgi kuramlarının da müfredata eklenmesi gerektiğini belirtmektedir. Ewick, Harding'in "güçlü nesnellik" diye adlandırdığı kavramı benimsiyor. Güçlü nesnellik sadece nesnellikten farklıdır. Nesnellik değer tarafsızlığıdır. Bu tanıma göre "iyi" bilim değerler, ilgiler ve tercihler ortadan kaldırılırsa gerçekleşebilir. "Saflı̆̆ bozan" ve "kirliler" ortadan kaldırıldığında geriye kalan -öyle düşünülüyor- dünyanın ta kendisidir. Bu nedenle dünya ancak araştırmacının öznel pozisyonu yok edilerek anlaşılabilir. Harding'e göre bu tür nesnellik çok güçsüz ve çok dar bir nesnelliktir. Oysa güçlü nesnellik, değerlerin yok edilmesini savunmaz, aksine onların kaçınılmazlığını araştırır. Bu bağlamda eleştirellik, aktif katılım gibi teknikler kullanılmalıdır. Bilgi bizim dışımızda "dışarılarda bir yerlerde" değildir, bilginin üreticileri bizleriz. Dolayısıyla feminist metodolojide ağırlıklı olarak ortaya konan bu düşünceyi araştırma yöntemleri ders içeriği ile bütünleştirebilmeliyiz (Ewick, 1994, 92-108).

Sandra Harding ve K. Norberg de makalelerinde, antropoloji, tarih, psikoloji, sosyoloji, ekonomi, uluslararası ilişkiler gibi sosyal bilimler alanına feminist eleştirinin uygulanma biçimlerinden söz etmektedirler (Harding, \& Norberg, 2005, 2009-2015).

\section{Çağdaş, Postmodern ve Postkolonyal (Sömürge sonrası) Tartışmalar}

Feminist eleştiri başlığında da değindiğimiz gibi postmodernistler tüm büyük anlatıları olduğu gibi feminizmi de eleştirmektedir. Bu iki akım, Batı Aydınlanması ile moderniteye ait büyük anlatılara karşı verdikleri mücadelede, aralarındaki benzerlikleri keşfetmişlerdir. Ancak sonuna kadar götürülen postmodernist konumlar, feminist kuramın özgüllügünü ortadan kaldırma tehlikesini de taşımaktadır (Benhabib, 2008, 29). Çağdaş tartışmalar, kadın araştırmaları içinde hemcinsler arasında olan çalışmaların da başka dinamiklerle etkilenebileceği gerçeğini tartışmaya açmışlardır. 1990'larda gelişen post-modern-feminist ve sosyalist-feminist yaklaşımlar, kadınlar ve cinsel yönelim gruplarının kendi içlerinde de sınıf, eğitim, ırk ve yaşa bağlı farklılıklar ve eşitsizlikler olduğuna işaret ederek araştırmacı-katılımcı ilişkisinde eşitlik iddialarını sorgulamışlardır. Buna göre toplumsal cinsiyet ve cinsellik araştırmalarında pozitivist ve niceliksel yaklaşımların yetersizliği kadar, araştırmacı-araştırılan ilişkisinin bir egemenlik ilişkisi olmasının da sorgulanması gereklidir (Mies, 1995, 48). Böylece aslında cinsiyetleri, toplumsal cinsiyet deneyimleri veya cinsel yönelimleri ortak olsa bile, araştırmacı-katılımcı ilişkisinin eşitlikçi ve kendini ifade etmeye açık olduğu iddiasının da tartışılabilir olduğu ortaya konmuştur. Birinci dönemden ikinci döneme geçiş, sosyal bilimler alanında tek yönlü araştırma geleneklerinden uzaklaşılması çok boyutluluğu esas alan toplumsal cinsiyet çalışmalarında yaş, sınıf, eğitim, ırk 
ve dini inanç gibi toplumsal boyutları da kapsayan çalışmaların önem kazanması ile, daha yavaş ve karmaşık bir süreç içermektedir. Batılı ve ataerkil analizin hakim olduğu sosyal bilim araştırmalarına toplumsal cinsiyet ve cinsellik boyutları katılarak, varolan tüm marjinal grupların baskın söylemler içinde yeterince temsil edilmediği gösterilmiştir. Bu dönemde kadın araştırmaları alanı kadınlığı sorgular ve kadının araştırma süreçlerindeki ikincil ve eşitliksiz konumunun nedenlerini irdeleyerek bu durumu dönüştürmeye yönelik projeler geliştirirken, erkek araştırmaları da popüler, akademik ve hatta terapi amaçlı olarak erkeklik rollerini yeniden tanımlamaya çalışmıştır (Aliefendioğlu, \& Özbilgin, 2001).

Feminist araştırma ve metodoloji tartışmalarında etkili olacak iki kavram söz konusudur: Güç ve düşünümsellik. Feminist araştırmacılar, araştırmalardaki katılımcılarla hiyerarşik olmayan arkadaşça ilişkiler geliştirerek araştırmalardaki güç değiş̧enliğini azaltacaklarını iddia etmişlerdir. Daha sonraki feministler araştırmada güç dengesizliğinin kaçınılmaz olduğuna değinmişlerdir. Bu nedenle şu andaki feminist bilimcilerin odak noktası, güç dengesizliğinden ziyade gücün bilgi üretimini ve üretim sürecini nasıl etkilediği ile ilgilidir. Bilgiyi kimin ürettiği ile ilgili sorular, "Bilen kişi kim olabilir? Kimin bilgisi? ve Kim, kimin için konuşuyor?" gibi sorular çağdaş feminist, postmodern ve sömürge sonrası araştırmalar için çok önemli hale geldi. Batılı siyah kadınlar, feministler, üçüncü dünyalı feministler, öteki, dışlama, ırkçılık ve etnosentrizm konularını öne çıardılar. İçinde olmak bilmenin tek koşulu değildir, diye düşünülmektedir. Feministler bu noktada başkaları adına konuşmanın, bilmenin ve başkalarını savunmanın olası tehlikelerini ifade ettiler. Düşünümsellik ise, bizim öznelliğimizin diğerlerinin yaşamlarına karışmış olması meselesi olarak alınıyor ve feminist eleştiride önemli bir dayanak noktası olan öznellik vurgusu eleştirilip, bunun batılı birinci dünyalı feminist araştırmacının üçüncü dünyalıları ötekileştirip, kendilerini merkeze koyma tehlikesini beraberinde getirebileceğini belirtiyor (Doucet, \& Mauthner, 2007, 36-42). Mohanty'e göre, üçüncü dünya feminizmlerinin entelektüel ve siyasal yapısına ilişkin bir tartışma aynı anda iki projeye yönelmelidir: Hegemonik "Batı" feminizmlerinin içeriden eleştirisi ve feminizmin coğrafi, tarihsel ve kültürel temellere dayanan bağımsız çalışma alanlarının ve stratejilerinin üretilmesi. İlk proje yapıbozumuna uğratmayı ve parçalarına ayırmayı, ikincisiyse temellendirmeyi ve yapılandırmayı gerektirir. Bunlar yapılmadıkça üçüncü dünya feminizmleri marjinalleşme ve gettolaşma tehlikesi ile yüz yüze kalacaktır. Bu nedenle öncelikle Batı feminizminde üçüncü dünya kadınlarının söylemsel yapısını çözümlemek gerekmektedir. Yazar Batı ve üçüncü dünya kavramlarının homojen olmadıklarını da özellikle belirtmektedir. Batılının gözünde üçüncü dünyalı kadınlar "kurbandır" (erkek şiddetinin, sömürgeci sistemin, Arap aile sisteminin, ekonomik gelişme sürecinin, vb.). Bu, kadınları, tarihdışı, genel kategoriler olarak düşünmek anlamına gelmektedir. Kısaca yazar batılı feminist bakışın üçüncü dünyaya bakışındaki hegemonyacı söylemin farkına varılması gerektiğini belirtmektedir (Mohanty, 2008, 25-63).

Bu konuyla ilgili Türkiye'den bir örnek verilebilir. Heidi Wedel'in "Yerel Alanda Siyasal Katılım ve Sosyal Yardımlaşma" isimli çalışması ve Jenny White'ın Para ile Akraba isimli kitabı, batılı feminist yazarların Türk toplumundaki kadını çözümlerken hegemonik bir gözlük takmaları ile ilgilidir. Tek kadından hareketle bütün kadınları çözümlemek, farklılı̆̆ın öte yanındaki herkesin aynı olduğu genel yargısından hareket etmek söz konusudur. Esasında işin tarihsel arka planı da mevcuttur. Geçmişte de batılı kadın seyyahın veya araştırmacının düşüncesinde doğulu kadın, döneme özgü çeşitli ideolojiler içinde kurban kadın olarak kurgulanmıştır. Batılı bilir ve öğretir, doğudaki onları dinler ve öğrenir. Olup biteni kendi gerçekliği içinde anlamaya çalışmak yerine önceden edinilmiş ideolojik bakış biçimleriyle olgulara ve gerçek yaşam deneyimlerine yaklaşmak, olguların yanlış anlaşılmasına sebep olduğu gibi kendi dünyası dışındaki kadın deneyimlerini de ikincilleştirme tehlikesi ile baş başa bırakır (Akgökçe, 2001, 53-75).

Feminist araştırma pratiği, araştıran ve araştırılan boyutunu uluslararası düzeyde yeniden biçim- 
lendirmek durumundadır, diyebiliriz.

\section{Sonuç ve Değerlendirme}

Feminist epistemoloji, geleneksel epistemolojilere büyük ölçüde benzemekle birlikte, ondan farklı, yeni görüşler, reform olanakları sunmaktadır. Ancak son yıllarda feminist epistemoloji, postmodern, post yapısalc1 ve sömürge sonrası düşüncelerle önemli ölçüde sekteye uğratıldı. Farklı görüş açılarını kabullenip, çoğulcu bir yöne yaklaştı. Feminist metodoloji pozitivizme getirdiği eleştiriler bağlamında genelde kabul görse de katılımlı gözlem ve deneyim tekniklerinin dışında aktivizm ve aksiyon ile ilgili teknikleri pek ilgi görmemektedir. Cancian'a göre burada feminist metodolojinin bilimsel bilgi standartlarını oluşturamaması, örneklem seçmek için sağlıklı veri tabanlarının oluşturulamaması, akademideki hiyerarşik güç ve prestij yapısı gibi nedenler yer almaktadır. Ancak feminist metodoloji pozitivist bilim üretme biçimini eleştirerek sarsmış ve bu gelenek içinde araştırmaya eylem katmak, katılımcı yaklaşım kullanmak, kadınları güçlendirmek gibi yeni teknikleri vurgulamıştır. Feminist araştırma, toplum içindeki çoklu hiyerarşileri ve eşitsizlikleri ortadan kaldırma hedefini güderek, nitel yöntem ve teknikleri ön plana alarak katı pozitivist ilkeleri sarsmaya devam etmektedir. Tüzel'in belirttiği gibi (2009, 545) feminist araştırma, değerden bağımsız olduğu varsayılan ideolojik araştırma biçimlerinin ve bilim anlayışının, stratejik bir bilgi edinme biçimi ile yer değiştirdiği; gerçekliğin bilgisine ulaşma iddiasını sorgulayan; gerçek ile onun bilgisi arasındaki ilişkinin çarpıtmaya uğratılmak yerine, niteliğinin açık edildiği bir yaklaşım içinde gerçekleşebilir. Bu yönüyle feminizm, sosyal bilimlerin "uyumlulaştıran", "ehlileştiren", "kategorize eden" ve "tanımlayan" hallerine karşı direnir. Sonuç olarak feminist araştırma yöntemi, sadece anlama ve açıklama amacını gütmeyen, kadınların yaşamlarını dönüştürme işlevini de yerine getirmeye çalışan bir yöntemdir. Yine feminist araştırma yöntemi farklı disiplinlerin çözümleme yöntemlerini de kullanarak amaçlarını gerçekleştirme konumundadır.

\section{KAYNAKÇA}

Akgökçe, N. (2001). "Kültürel Prizmanın Işı̆̆ında Farklılıklar, Batılı Kadın Uzmanların Gözüyle Türkiye'deki Kadın”. Ed. İlyasoğlu A.-Akgökçen. Yerli Bir Feminizme Doğru, 53-76. İstanbul: Sel Yayıncilik.

Aliefendioğlu, H., \& Özbilgin M. (2001). "Kadın, Toplumsal Cinsiyet ve Cinsellik Araştırmalarında Araştırmacı ve Katılımcı İlişkisi: Yeni Arayışlar ve Yönelimler”. Kadın/Woman 2000, II/II.

Benhabib, S. (2008). "Feminizm ve Postmodernizm: Huzursuz Bir İttifak". Ed. Benhabib, S., Butler, J., Cornell, D., \& Fraser, N. Çatışan Feminizmler. Metis.

Benton, T., \& Craib, I. (2008). Sosyal Bilim Felsefesi. Ed. Tatlıcan, Ü., \& Binay, B. Bursa: Sentez Yayınc1lk.

Cancian, F. (1992). "Feminist Science: Methodologies that Challenge Inequality". Gender and Society, 6, 623-642.

Cook, J., \& Fonow, M. M. (1986). "Knowledge and Women's Interest: Issues of Epistemology and Methodology in Feminist Sociological Research". Sociological Inquiry, 56 1. 2-29.

Çakır, S. (1995). "Türkiye'de Kadın Tarihini Yazmak”. Ed. Çakır, S., Akgökçe N., Farklı Feminizmler Açısından Kadın Araştırmalarında Yöntem, 222-230. İstanbul: Sel Yayıncılık.

Çakır, S. (1996). "Kadın Araştırmaları Bilimde Neleri, Nasıl sorguluyor, Neleri Değiştirmek İstiyor?". Ed. Kuvvet L. İnsan, Toplum, Bilim. 305-317. İstanbul: Kavram Yayınları.

Çimrin, F. (2006). "Kendisine Gelecek Hazırlayan Bir Alan Olarak 1980 Sonrası Türkiye'de Kadın Çalışmaları". Kadın Çalı̧̧maları Dergisi, 1, 3, 142-151.

Demir, Ö. (2012). Bilim Felsefesi. İstanbul: Sentez Yayıncılık.

Demir, Z. (1997). Modern ve Postmodern Feminizm. İstanbul: İz yayıncılık. 
Donovan, J. (2010). Feminist Teori. Çev. Aksu, B., Gevrek, M., \& Sayılan, F. İstanbul: İletişim Yayınları.

Doucet, A., \& Mauthner, S. N. (2007). "Feminist Methodologies and Epistemology". Ed. Bryant, D. C., \& Peck, L. D. 21 st Century Sociology, II/II, 36-42.

Ecevit, Y. (1996). "Türkiye'de Kadın çalışmaları: Durum, Sorunlar ve Gelecek". Akademik Yaşamda Kadın. Ankara: Türk-Alman İşleri Kurulu.

Ewick, P. (1994). "Integrating Feminist Epistemologies in Undergraduate Research Methods". Gender and Society, VIII/ 1 92-108.

Fraser, N., \& Nicholson, L. (1994). "Felsefesiz Toplumsal Eleştiri: Feminizm ve Postmodernizm Arasında Bir Karşılaşma". Çev., Mehmet Küçük. Ed. Mehmet Küçük. Modernite versus Postmodernite. 305-317. Ankara: Vadi.

Gorelick, S., (1991). "Contradictions of Feminist Methodology". Gender and Society, 5/4, 459-477.

Harding, S., \& Norberg, K., (2005). "New Feminist Approaches to Social Science Methodologies: An Introduction". Signs: Journal of Women in Culture and Society, 30/4, 2009-2015.

Kandiyoti, D. (1995). "Ataerkil Örüntüler: Türk Toplumunda Erkek Egemenliğinin Çözümlenmesine Yönelik Notlar”. Ed. Ş. Tekeli. 1980’ler Türkiye'sinde Kadın Bakış Açısından Kadınlar, 367-382, İstanbul: İletişim Yayınları.

Karaduman, A. B. (2006) "Kadın Araştırmalarında Yeni Yaklaşımlar II". Kadın Çalışmaları Dergisi, 3 89-93.

Keat, R., \& Urry, J. (1994). Bilim Olarak Sosyal Teori. Çev. Nilgün Çelebi. Ankara: İmge Yayınları

Kırca, S. (2001) "Feminist Kültürel Çalışmalarda Kuram ve Yöntem Tartışmaları: Dünyadan Türkiye'ye Açılan Pencere". Toplumbilim, 25-31.

Kümbetoğlu, B., (2005). Sosyolojide ve Antropolojide Niteliksel Yöntem ve Araştırma. İstanbul: Bağlam Yayıncilik.

Marshall, G., (1999), Sosyoloji Sözlüğü. Çev. O. Akınhay, D. Kömürcü. İstanbul: Bilim ve Sanat Yayıncilik.

McCarthy, E. D. (2002). Bilgi Kültürü. Çev. Figen Yılmaz. İstanbul: Çiviyazıları Yayınevi.

Mies, M. (1995). "Feminist Araştırmalar için Bir Metodolojiye Doğru". (Çev. Ayşe Durakbaşa), Ed. Aynur İlyasoğlu, Serpil Çakır, \& Necla Akgökçe. Farklı Feminizmler Açısından Kadın Araştırmalarında Yöntem, 48-67. İstanbul: Sel Yayıncılık.

Mohanty, C. T. (2008). Sinır Tanımayan Feminizm, Teoriyi Sömürgeleştirilmekten Kurtarmak, Dayanışmayı Örmek. İstanbul: Boğaziçi Üniversitesi Yayınevi.

Ritzer, G. (2005). "Feminist Epistemology" . Ed. Mary F. Rogers, \& Jennifer Pemberton. Encyclopedia of Social Theory, 271-274. Sage.

Sancar, S. (2003). "Üniversitede Feminizm? Bağlam, Gündem ve Olanaklar”. Toplum ve Bilim 97, 164-182.

Sunar, L., \& Şentürk, M. (2006). "Kadın Çalışmaları Genellikle Feminizmle İç İçe Geçer" Prof. Dr. Serpil Sancar Üşür ile yapılan röportaj. Kadın Çalış̧maları Dergisi, 3, 158-163.

Timisi, N. (2002-2003). "Üniversitelerde Kadın Çalışmaları Toplantısı'nın Ardından”. Toplum ve Bilim, 95, Kiş, 202-207.

Tüzel, G. B. (2009). "Feminist Bir Doktora Tezi Yazmak". Ed. Dilek Hattatoğlu, \& Gökçen Ertuğrul. Methodos: Kuram ve Yöntem Kenarından, 527-551. İstanbul: Anahtar Kitaplar.

Wallace, R., \& Wolf, A. (2004). Çă̆daş Sosyoloji Kuramları. Çev. Leyla Elburuz, \& M. Rami Ayas. İzmir: Punto Yayıncılık.

Wolf, D. L. (2009). "Saha Çalışmasında Feminist İkilemler". Çev. Dilek Hattatoğlu, \& Gökçen Ertuğrul Ed. Methodos: Kuram ve Yöntem Kenarından, 372-442. İstanbul: Anahtar Kitaplar. 